\title{
Italian university spinoffs vs Italian innovative companies: a comparative analysis of profitability, liquidity and efficiency profile
}

\author{
Anna Paola Micheli ${ }^{1}$, Carmelo Intrisano ${ }^{1}$, Anna Maria Calce ${ }^{1}$ \\ ${ }^{1}$ Anna Paola Micheli, Assistant Professor in Corporate Finance, University of Cassino and Southern Lazio, Italy. \\ ${ }^{2}$ Carmelo Intrisano, Full Professor in Corporate Finance, University of Cassino and Southern Lazio, Italy. \\ ${ }^{3}$ Anna Maria Calce, PhD and Research Fellow in Corporate Finance, University of Cassino and Southern Lazio, \\ Italy.
}

\begin{abstract}
This paper, as part of the PRIN "University spin-offs: competitiveness, attractiveness and value", intends to increase the knowledge on the performance of university spinoffs, studied until now especially for the dynamics of constitution and development that characterize them. The study attempts primarily to measure the financial performance of Italian university spinoffs and Italian innovative start-ups and SMEs. Furthermore, it aims to determine whether the Italian academic spinoffs's financial condition tends to be different respect to Italian innovative companies. In order to reach these objectives, the financial statement analysis, with financial ratios to ascertain profitability, liquidity and efficiency profile, and the t-test have been used. University spinoffs have higher value of ratios if compared to innovative startups and SMEs. Furthermore, t-test highlights the existence of significant differences in the profitability, liquidity, structure and efficiency profile between two groups of companies.
\end{abstract}

Keywords: university spinoffs, innovative companies, financial performance, financial ratios

DOI: $10.7176 /$ RJFA/12-23-05

Publication date: December $31^{\text {st }} 2021$

\section{Introduction}

In recent year the role of universities has been changing, assuming today as a basilar pillar in the construction of knowledge societies. As a result of the changing in the cultural and social environmental in which universities play a relevan role, have been assuming an increasing emphasis in any discussion about the production, diffusion and conversion of knowledge in economic and social value. Recent studies show that university spin-offs stimulate socio-economic innovation, create significant social impacts and economic benefits for local communities, new jobs and wider research opportunities for university staff (Stefanelli et al., 2020; Peng, 2006). Most of the studies on university spin-offs have been directed at the relationship between resources, performance and the degree of survival, concluding that the synergistic interaction between resources is relevant for growth. Other researchers have investigated the effect that patents have on the birth of spin-offs. Furthermore they show the importance of public incentives, as well as the entrepreneurial training and incubation initiatives provided for university spin-offs. The analysis on performance have highlighted difficulties of investigation linked to the volatility of the results which would make insignificant the traditional financial ratio. In this regard, in the literature the most investigated business variables are profitability, turnover, assets and the variation of number of employees. In other studies the risk profile, the degree of innovation and the number of patents, the presence of venture capitalists were considered. Another topic concerns the quality of human resources, essential for the success and growth of university spin-offs. Researchers with a low academic profile generally create less innovative spin-offs. The most qualified researchers promote spin-offs with greater potential, being able to interact with important scientific networks and with business system of reference. However, if the academic profile of the founders is a guarantee of scientific excellence, it can also represent a critical element if not accompanied by specific entrepreneurial/managerial skills and a predisposition to participate actively in the entrepreneurial project. Researchers often prefer to maintain their commitment in the academic activity rather than in the spin-off considered risky and uncertain; this can compromise the entire business activity. Considering 
the financial provision, equity raising encounters a limit in the low inclination of academic staff to contribute with their own resources to entrepreneurial initiatives (Zapata-Guerrero, 2020). University spin-offs, on the other hand, can rely on specific public funding; moreover, informal investors are increasingly present in the stock market, such as incubators, business angels (Bessière et al., 2020;), venture capitalists (Cumming and Zambelli, 2017; Cumming and Zambelli, 2013; Zambelli, 2014) and, more recently, equity crowdfunding (Daldrup et al ., 2020) and venture philanthropy (Bessière et al., 2020), naturally interested in investing in companies with high development and growth potential. However, their participation in the risk capital of the spin-offs is still limited, especially in Italy (Stefanelli et al., 2020). Likewise, the collection of debt capital has the limit given by the lack of effective methodologies for rating evaluation not based on exclusively quantitative-financial parameters. The state of the art, therefore, does not show significant contributions on the performance and value of university spin-offs and indicates the absence of knowledge on the risks underlying their financing and on the consequent financial barriers that prevent their growth in terms of competitiveness. Starting from this gap in literature, the study aims to increase the knowledge on the performance of university spinoffs, studied until now for their dynamics of constitution and development, and to identify any differences with respect to innovative companies.

\section{Literature review}

Rothaermel et al. (2007) were the first authors to perform a literature review in the field of university entrepreneurship. They identified four streams in this area of study: (i) entrepreneurial research university, (ii) productivity of technology transfer offices, (iii) new firm creation, and (iv) environmental context including networks of innovation. University spin-offs (USOs) are very special start-up companies and for this they are not fully comparable to other companies. The USOs have been studied giving rise to a huge and growing literature. The definitions are various but all of them refer to the transfer of knowledge and technologies from the university to the academic spin-off. The transferred technology might be formalized intellectual property, e.g. the transfer of a patent via technology licensing (Di Gregorio and Shane, 2003). Alternatively, the transfer may consist of non-formalized technologies and research results (Djokovic and Souitaris, 2008). The discussion on transferred knowledge and technologies usually focusses on research results from natural sciences, computer sciences or engineering.

The literature on academic spin-off presents definitions, typologies, and stages of development of academic spinoffs (Clarysse and Moray, 2004; Nicolaou and Birley, 2003) and best practices of TTOs toward spin-offs (Rothaermel et al., 2007). Egeln et al. (2003) relax the criterion that academic spin-offs must commercialize universities' research results and denote as competence spin-offs those start-ups for which special skills and expertise the founders acquired at a university were essential to create the new firm. In recent years, universities have focused more on the creation of spin-off companies as a means of transferring the knowledge generated by their research activities. Scholars have proposed over the years different definition of spin-off. Roberts and Malone (1996), for example, defined spin-offs as a mechanism in which governments seek to generate economic impact from their R\&D, by transferring technology from the R\&D function to a commercial organization. In the same way, Rogers and Takegami (2001) defined spin-offs as those companies based on the parent R\&D organizations, namely, the government $\mathrm{R} \& \mathrm{D}$ laboratory, the University, the University research center, and private R\&D organizations. Nicolaou and Birley (2003) proposed a definition of spin-off that takes into account the human element of the spin-off itself. According to Castillo-Vergara (2015) quoting Beraza and Rodríguez (2012), USOs are entrepreneurial initiatives supported by members of the university community who base their activities on the enhancement of new processes, products and services on the knowledge acquired and the results obtained at the University.

Shane (2004) defined an academic spin-off as "those high-tech companies whose core business is based on the commercial valorization of results of a scientific and technological research". More recently, Conti et al. (2011) defined spin-off companies as "those companies that germinate from a University, where a group of researchers compose the entrepreneurial unit aiming at the exploitation of skills and results from the research developed within the University". Regardless the definition adopted, it is possible to state that an academic spin-off involves the transfer of a core technology from an academic institution into a new company, and whose founders may include the inventor academic who may or may not be currently affiliated with the academic institution.

In terms of their impact at the university-level, research has shown that universities' research quality and orientation (Crespi et al., 2011; Di Gregorio and Shane, 2003), and the universities' IP policies (Lach and Schankerman, 2004, 2008; Goldfarb and Henrekson, 2003), influence this decision. At the regional level, the 
strength of the local cluster and the availability of early stage investors influence this decision (Friedman and Silberman, 2003; Lockett and Wright, 2005; Powers and McDougall, 2005; Shane and Stuart, 2002).

Although academic entrepreneurship has been a phenomenon that has existed, in particular in the experiences of USA University which first gave the birth to this particular form of entrepreneurship, only recently has taken a prominent place in the political agendas of governments. Nowadays, the race to knowledge, to innovation, and to science and technology is global and has a direct impact on the economic performance, growth and prosperity of all regions. On this point of view Siegel and Wright (2015) identified two changes since 2012: first, the involvements of more stakeholders in the process of academic entrepreneurship; second, universities have become more strategic in their approach to this activity. More recently, Fini et al. (2016) performed a longitudinal and multi-level cross country study (i.e., Italy, Norway, and UK) to test whether the national and university level initiatives have an influence on the number and quality of those created spin-offs. Scholars believe that USOs are important for regional economic development (Astebro and Bazzazian, 2011; Bramwell and Wolfe, 2008; Breznitz et al., 2008; Breznitz and Feldman, 2012). The well-known examples of new industrial cluster growth such as Silicon Valley in California (Saxenian, 1996), Route 128 in Massachusetts (Saxenian, 1996).

The literature review has selected a void with regard Italy especially in the empiric studies aimed to identify the USOs' financial performance. The work aims to fill the gap and contribute to the research on the subject proposing a comparison between USOs and innovative start-ups.

\section{Methodology}

In this paper data from multiple balance sheets and income statements are compared over time and space using the financial statement analysis (Lev, 1974; Foster, 1986; Ou and Penman, 1989; Chukwunweike, 2014; Rinaldo and Endri, 2020; Mun and Tashmanov, 2021; Solanki and Devmurari, 2021). The over time analysis refers to the comparison of data from the same company, while comparison over space means the confrontation of data from different companies. The analysis concerns Italian university spinoffs vs Italian innovative startup and SMEs. University spinoffs and innovative companies have been identified through the portals SpinoffItalia and Startup Infocamere respectively. Profitability, structure and efficiency ratios have been computed using data on financial statements gathered from Amadeus Bureau Van Dijk for the period 2018-2020.

The objectives of this study are:

- $\quad$ to investigate the profitability, liquidity, structure and efficiency profile of univeristy spinoffs and innovative companies;

- $\quad$ to compare the profitability, liquidity, structure and efficiency status of university spinoffs and innovative companies;

Adopting the ratio analysis method, the analysis focuses on these indicators: ROE, ROA, Profit margin, EBITDA margin, EBIT margin AND Cash flow/Operating revenue ratio for the profitability; Current ratio, Liquidity ratio, Shareholders liquidity ratio, Solvency ratio and Gearing ratio for the liquidity and structure analysis. Profit per employee, Operating revenue per employee, Cost of employee/Operating revenue ratio, Average cost of employee, Working capital per employee and Total asset per employee are used in the study of the efficiency profile.

Additionally, to examine whether the difference in profitability, liquidity, structure and efficiency of the innovative companies is statistically different from that of university spinoff, the Student's t- test is employed to check the hypothesis that the means of the two samples are the same. Specifically, hypothesis testing is based on the following provisions to be verified:

$\mathrm{H}_{0}$ : there is no significant difference in terms of profitability among innovative companies and university spinoffs;

$\mathrm{H}_{1}$ : there is significant difference in terms of profitability among innovative companies and university spinoffs;

$\mathrm{H}_{0}$ : there is no significant difference in terms of liquidity and structure among innovative companies and university spinoffs; 
$\mathrm{H}_{1}$ : there is significant difference in terms of liquidity and structure among innovative companies and university spinoffs;

$\mathrm{H}_{0}$ : there is no significant difference in terms of efficiency among innovative companies and university spinoffs;

$\mathrm{H}_{1}$ : there is significant difference in terms of efficiency among innovative companies and university spinoffs.

Looking at test statistics and critical values associated with the mean, it is possible to make inferences about the hypothesis. So, for P-value $\leq \alpha(\alpha=0.05)$ the null hypothesis is rejected. For P-value $>\alpha(\alpha=0.05)$, the null hypothesis is accepted.

\section{Results and discussions}

Objective 1): to investigate the profitability, structure and efficiency profile of university spinoffs and innovative companies.

The following table resume the profitability ratios for innovative startup and SMEs. They record negative ROE for the period 2018-2019. Innovative startup and SMEs have recorded a ROE of $-4.10 \%$ in 2018 which reached $4.71 \%$ in 2020 . The ROA in 2018 stood at a value of $0.20 \%$ to then reach $0.34 \%$ in 2020 , recording a worsening in $2019(-0.22 \%)$. Profit margin in 2018 is $2.30 \%$ showing a progressive decrease in the following two years until reaching $0.83 \%$ in 2020 . The same downward trend can be observed for the EBITDA margin: starting from an average value of $9.05 \%$ in 2018 , the ratio decreases assuming the value of $8.56 \%$ and $7.91 \%$ in 2019 and 2020 respectively. The EBIT margin also shows a reduction: from the $3.51 \%$ recorded in 2018 , it drops to an average value of $1.84 \%$ in 2020 . The Cash flow/Operating revenue ratio remains constant at $6.65 \%$ in 2018 and 2019 and then decreases to $6.03 \%$ in 2020 .

Table 1. Innovative startup \& SMEs: profitability ratios

\begin{tabular}{lrrr}
\hline Innovative startup \& SMEs & $\mathbf{2 0 1 8}$ & $\mathbf{2 0 1 9}$ & $\mathbf{2 0 2 0}$ \\
\hline ROE (\%) & -4.10 & -3.93 & -4.71 \\
ROA (\%) & 0.20 & -0.22 & 0.34 \\
Profit margin (\%) & 2.30 & 1.42 & 0.83 \\
EBITDA Margin (\%) & 9.05 & 8.56 & 7.91 \\
EBIT Margin (\%) & 3.51 & 2.37 & 1.84 \\
Cash flow / Operating revenue (\%) & 6.65 & 6.65 & 6.03 \\
\hline
\end{tabular}

Average values

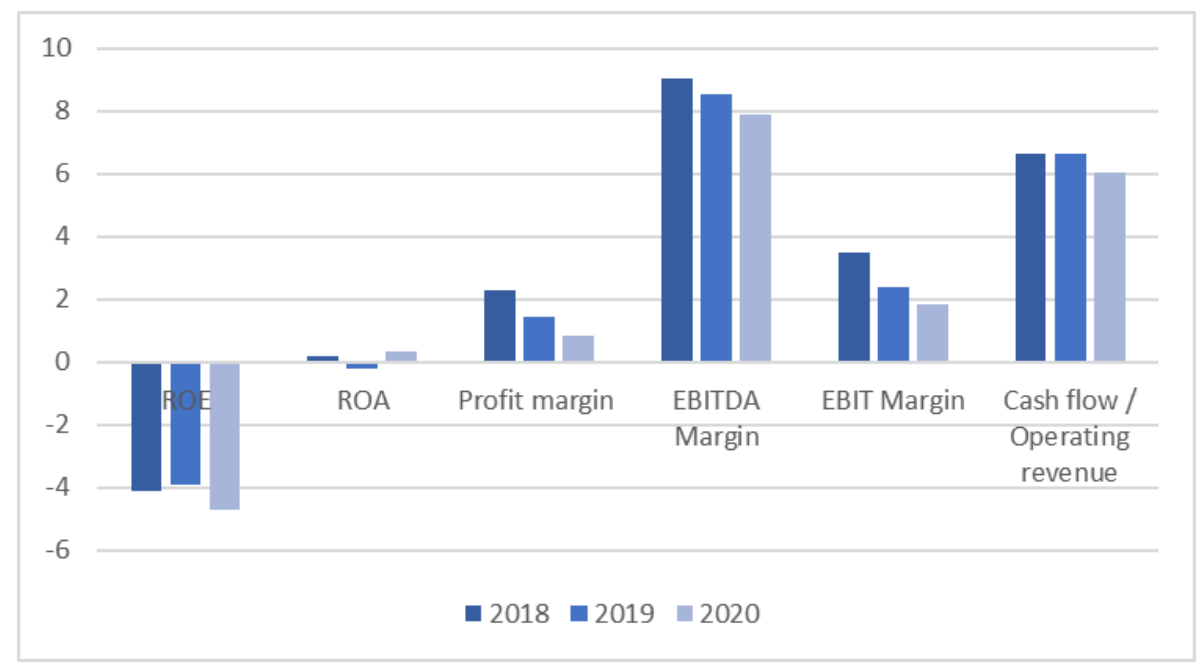

Figure 1. Innovative startup \& SMEs: profitability ratios

Investigating the liquidity status, innovative startup and SMEs respect the condition of short-term financial equilibrium. The values assumed by the current ratio and by the liquidity ratio show that current assets ensure coverage of current liabilities. Current ratio assumes an average value of 2.46 in 2018, dropped to 2.24 in 2019 
and rised again to 2.39 in 2020 . Liquidity ratio hires an average value of 2.29 in 2018; in the following two years it is reduced to 2.07 and then increased to 2.22 . The shareholders liquidity ratio progressively increases from 14.81 in 2018 to 16.21 in 2019 and finally to 17.07 in 2020 .

Table 2. Innovative startup \& SMEs: liquidity ratios

\begin{tabular}{lrrr}
\hline Innovative startup \& SMEs & $\mathbf{2 0 1 8}$ & $\mathbf{2 0 1 9}$ & $\mathbf{2 0 2 0}$ \\
\hline Current ratio (x) & 2.46 & 2.24 & 2.39 \\
Liquidity ratio (x) & 2.29 & 2.07 & 2.22 \\
Shareholders liquidity ratio (x) & 14.81 & 16.21 & 17.07 \\
\hline
\end{tabular}

Average values

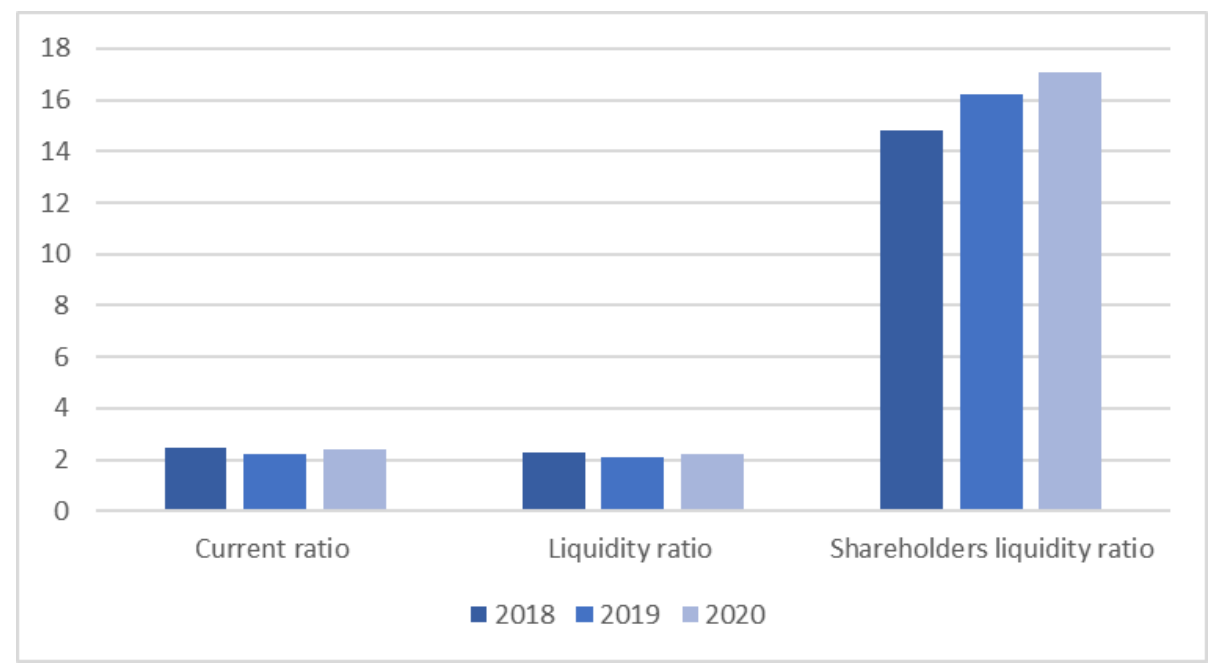

Figure 2. Innovative startup \& SMEs: liquidity ratios

For the structure status, analysis show that innovative startup and SMEs have an average Solvency ratio with an increasing trend in the considered period: starting from a value of $32.31 \%$, it progressively increases until it reaches $36.50 \%$ in 2020 . The average incidence of debt on shareholders' equity expressed through the Gearing ratio records a reduction, going from $126.30 \%$ in 2018 to $122.94 \%$ in 2020 .

Table 3. Innovative startup \& SMEs: structure ratios

\begin{tabular}{lrrr}
\hline Innovative startup \& SMEs & $\mathbf{2 0 1 8}$ & $\mathbf{2 0 1 9}$ & $\mathbf{2 0 2 0}$ \\
\hline Solvency ratio (Asset based) (\%) & 32.31 & 33.85 & 36.50 \\
Gearing (\%) & 126.30 & 123.06 & 122.94 \\
\hline A
\end{tabular}

Average values 


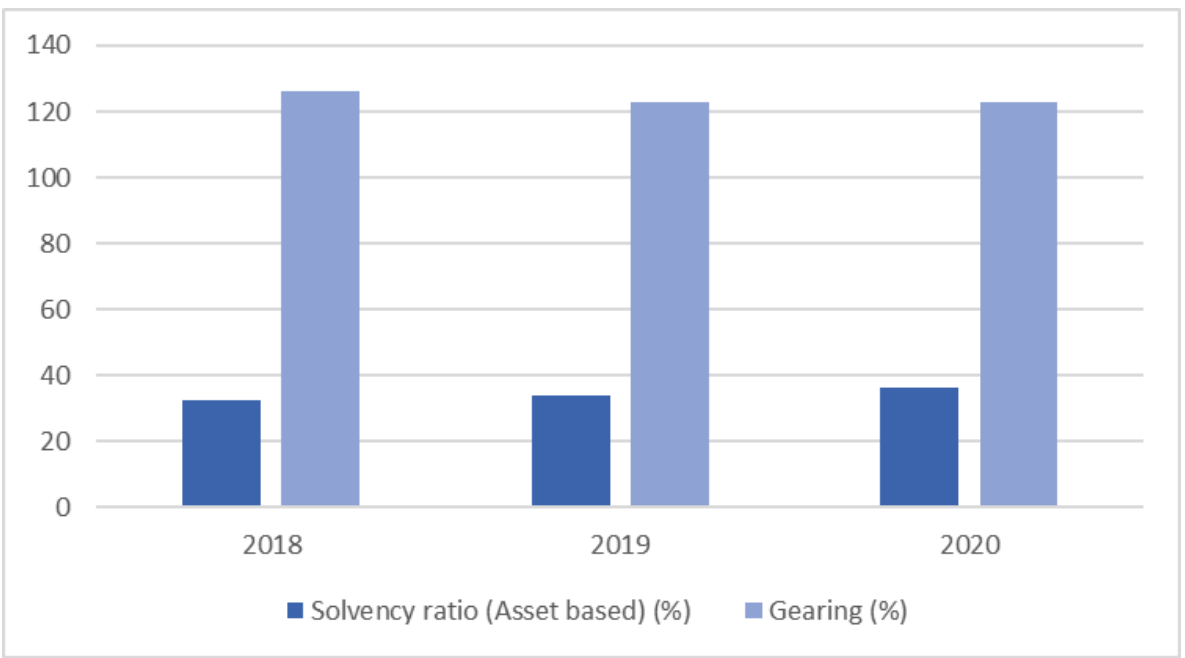

Figure 3. Innovative startup \& SMEs: structure ratios

Regarding the efficiency status, profit per employee assumes an average value of 19.19 th euro in 2018, decreases to 15.51 th euro in 2019 and then rises to 2020. A progressive increase in the average operating revenue per employee can be observed: the ratio starts from an average value of 240.16 th euro in 2018 and then settles at 246.87 th euro and 278.76 th euro in 2019 and 2020 respectively. The average cost of employee is 38.56 th euro in 2018, increased to 40.72 th euro in 2019 and reduced to 39.77 th euro in 2020. Working capital per employee shows an increasing trend from 45.10 th euro to 50.50 th euro in 2020. Same trend can be observed for Total assets per employee passed from 399.89 th euro to 572.98 th euro.

Table 4. Innovative startup \& SMEs: efficiency ratios

\begin{tabular}{lrrr}
\hline Innovative startup \& SMEs & $\mathbf{2 0 1 8}$ & $\mathbf{2 0 1 9}$ & $\mathbf{2 0 2 0}$ \\
\hline Profit per employee (th euro) & 19.19 & 15.51 & 18.83 \\
Operating revenue per employee (th euro) & 240.16 & 246.87 & 278.76 \\
Average cost of employee (th euro) & 38.56 & 40.72 & 39.77 \\
Working capital per employee (th euro) & 45.10 & 46.83 & 50.50 \\
Total assets per employee (th euro) & 399.89 & 432.04 & 572.98 \\
\hline
\end{tabular}

Average values

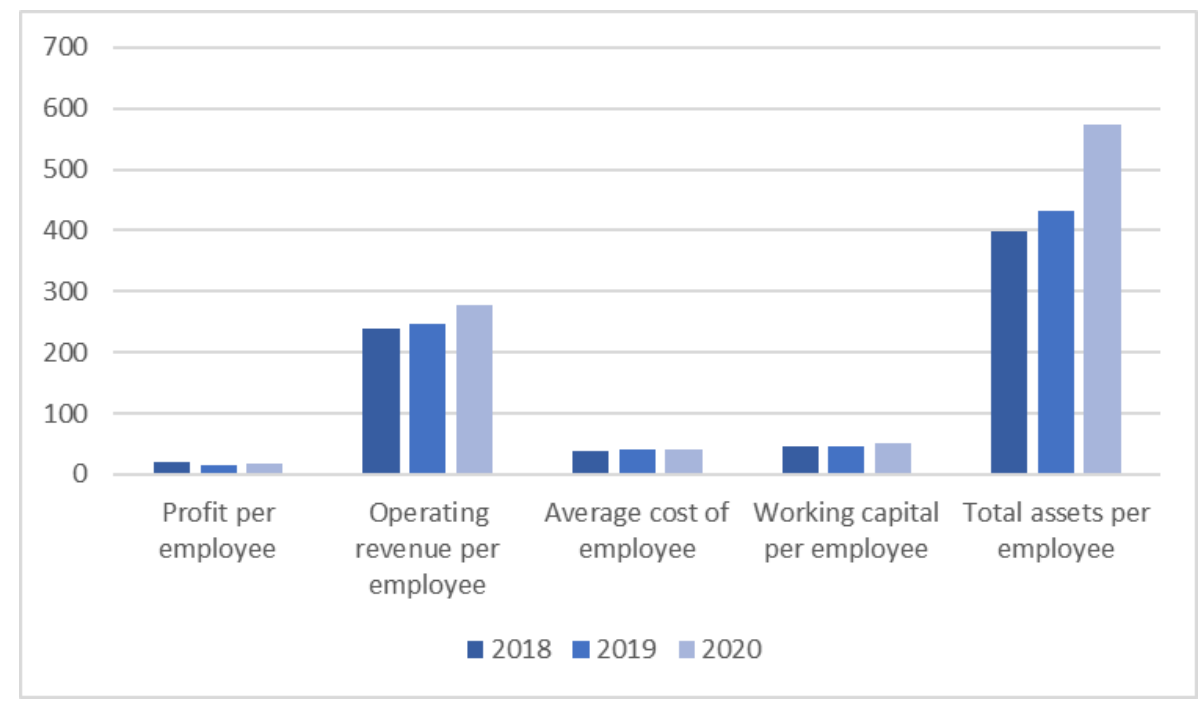

Figure 4. Innovative startup \& SMEs: efficiency ratios 
ROE of university spinoffs passes from $2.93 \%$ in 2018 to $5.73 \%$ in 2020 . On the contrary, the ROA records a decreasing trend: starting from $5.64 \%$ it stood at $4.62 \%$ in 2019 up to $3.56 \%$ in 2020 . Profit margin from $6.84 \%$ grows to $7.77 \%$ in 2019 and reaches $7.38 \%$ in 2020 . EBITDA margin starting from an average value of $10.46 \%$ in 2018 , rises to $12.89 \%$ in 2019 an then recorded a slight reduction, settling at $12.41 \%$. The same trend can be observed for EBIT margin which starts from $7.48 \%$ in 2018 , goes up to $8.49 \%$ in the following year and then drops to $7.66 \%$ in 2020 . Cash flow/Operating revenue ratio is mostly stable at $9 \%(9.41 \%$ in $2018 ; 9.16 \%$ in $2019 ; 9.13 \%$ in 2020).

Table 5. University spinoffs: profitability ratios

\begin{tabular}{lrrr}
\hline University spinoffs & $\mathbf{2 0 1 8}$ & $\mathbf{2 0 1 9}$ & $\mathbf{2 0 2 0}$ \\
\hline ROE (\%) & 2.93 & 11.98 & 5.73 \\
ROA (\%) & 5.64 & 4.62 & 3.56 \\
Profit margin (\%) & 6.84 & 7.77 & 7.38 \\
EBITDA Margin (\%) & 10.46 & 12.89 & 12.41 \\
EBIT Margin (\%) & 7.48 & 8.49 & 7.66 \\
Cash flow / Operating revenue (\%) & 9.41 & 9.16 & 9.13 \\
\hline
\end{tabular}

Average values

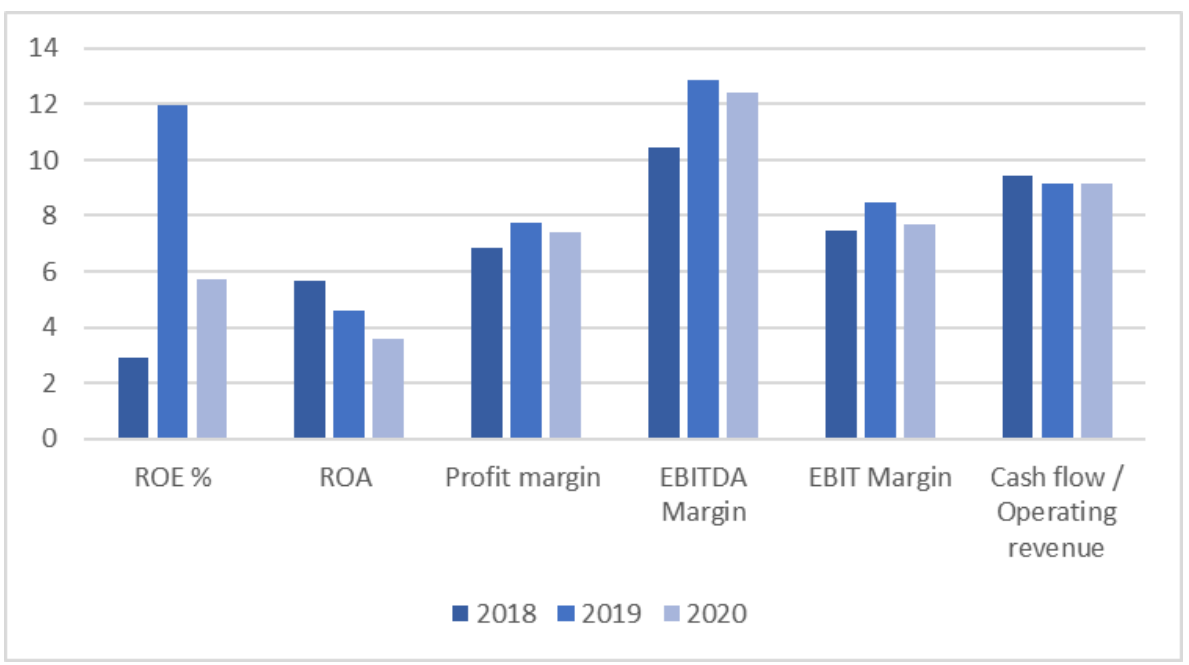

Figure 5. University spinoffs: profitability ratios

For the liquidity status, university spinoffs are in a state of financial equilibriums. Current ratio has an average value of 2.79 in 2018, increased to 3.39 and 3.47 in 2019 and in 2020 respectively. Liquidity ratio assumes an average value of 2.64 in $2018,3.16$ in 2019 and 3.28 in 2020. The shareholders liquidity ratio reduces from 14.65 in 2018 to 13.70 in 2019 and goes up to 17.12 in 2020.

Table 6. University spinoffs: liquidity ratios

\begin{tabular}{lrrr}
\hline University spinoffs & $\mathbf{2 0 1 8}$ & $\mathbf{2 0 1 9}$ & $\mathbf{2 0 2 0}$ \\
\hline Current ratio (x) & 2.79 & 3.33 & 3.47 \\
Liquidity ratio (x) & 2.64 & 3.16 & 3.28 \\
Shareholders liquidity ratio (x) & 14.65 & 13.70 & 17.12 \\
\hline
\end{tabular}

Average values 


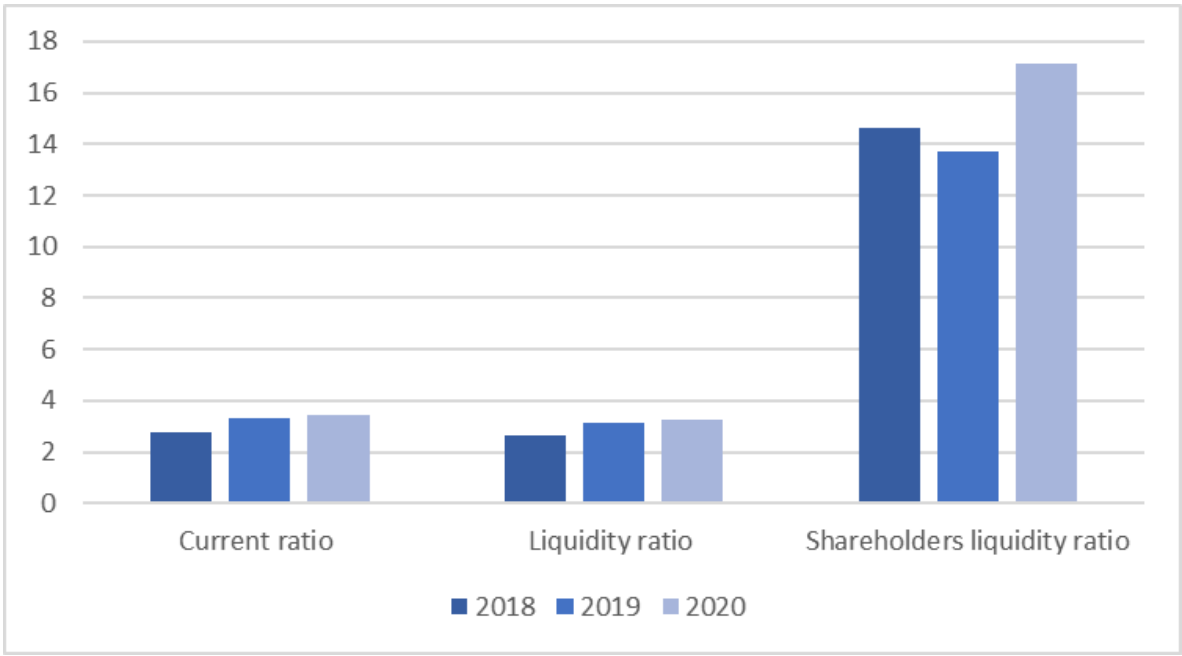

Figure 6. University spinoffs: liquidity ratios

For the structure profile, academic spinoffs have an average Solvency ratio costant in 2018 and 2019 on an average value of $39.85 \%$, and then increasing to $44.98 \%$ in 2020 . The average Gearing ratio passes from $94.50 \%$ in 2018 to $90.41 \%$ in 2019 and $83.33 \%$ in 2020 .

Table 7. University spinoffs: structure ratios

\begin{tabular}{lccc}
\hline University spinoffs & $\mathbf{2 0 1 8}$ & $\mathbf{2 0 1 9}$ & $\mathbf{2 0 2 0}$ \\
\hline Solvency ratio (Asset based) (\%) & 39.86 & 39.85 & 44.98 \\
Gearing (\%) & 94.50 & 90.41 & 83.33 \\
\hline
\end{tabular}

Average values

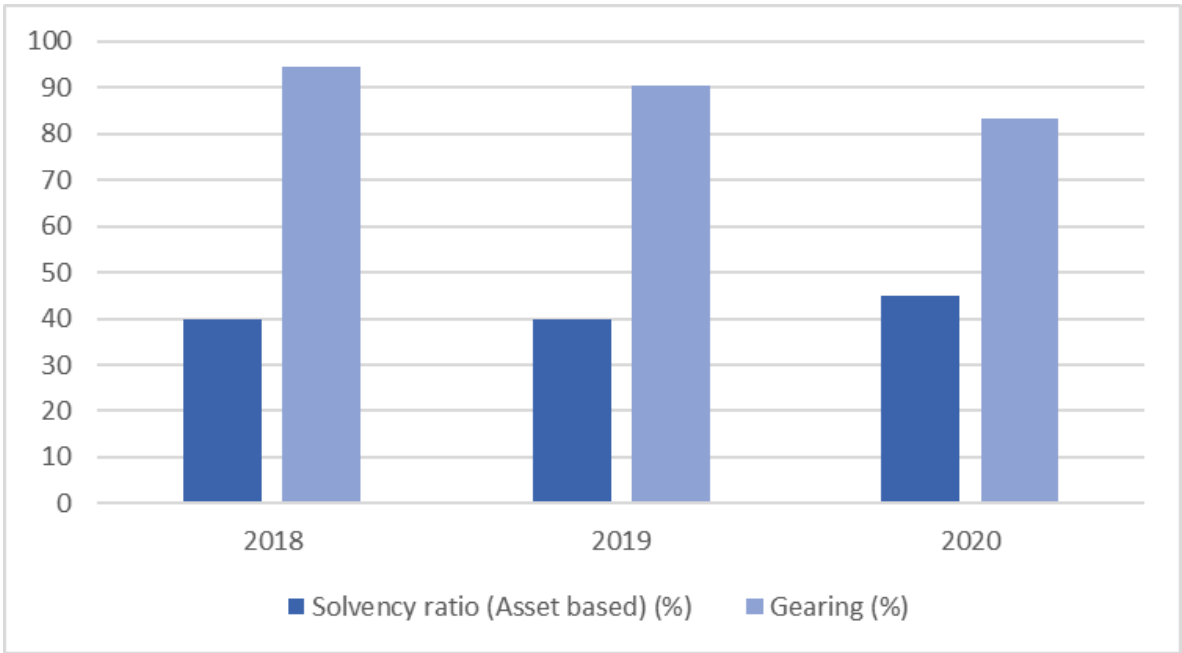

Figure 7. University spinoffs: structure ratios

With respect to efficiency profile profit per employee has an average value of 20.35 th euro in 2018 , increased to 30.72 the euro in 2019 and reduced to 22.20 th euro in 2020 . The average operating revenue per employee grows between 2018 and 2019, assuming the value of 181.36 th euro and 186.22 th euro respectively; then it reduces by passing to 161.32 th euro. In the three-year period, an increase in the average cost of employee is observed, from 43.64 th euro in 2018 , to 45.60 th euro in 2019, until it assumes a value of 46.39 th euro in 2020 . Working capital per employee grows continuously, passing from 38.78 th euro to 52.51 th euro in 2019 and to 60.70 th euro in 2020. Total asset per employee assumes an average value of 284.91 th euro in $2018,387.85$ th euro in 2019 and 418.62 th euro in 2020. 
Table 8. University spinoffs: efficiency ratios

\begin{tabular}{lrrr}
\hline University spinoffs & $\mathbf{2 0 1 8}$ & $\mathbf{2 0 1 9}$ & $\mathbf{2 0 2 0}$ \\
\hline Profit per employee (th euro) & 20.35 & 30.72 & 22.20 \\
Operating revenue per employee (th euro) & 181.36 & 186.22 & 161.32 \\
Average cost of employee (th euro) & 43.64 & 45.60 & 46.39 \\
Working capital per employee (th euro) & 38.78 & 52.51 & 60.70 \\
Total assets per employee (th euro) & 284.91 & 387.85 & 418.62 \\
\hline
\end{tabular}

Average values

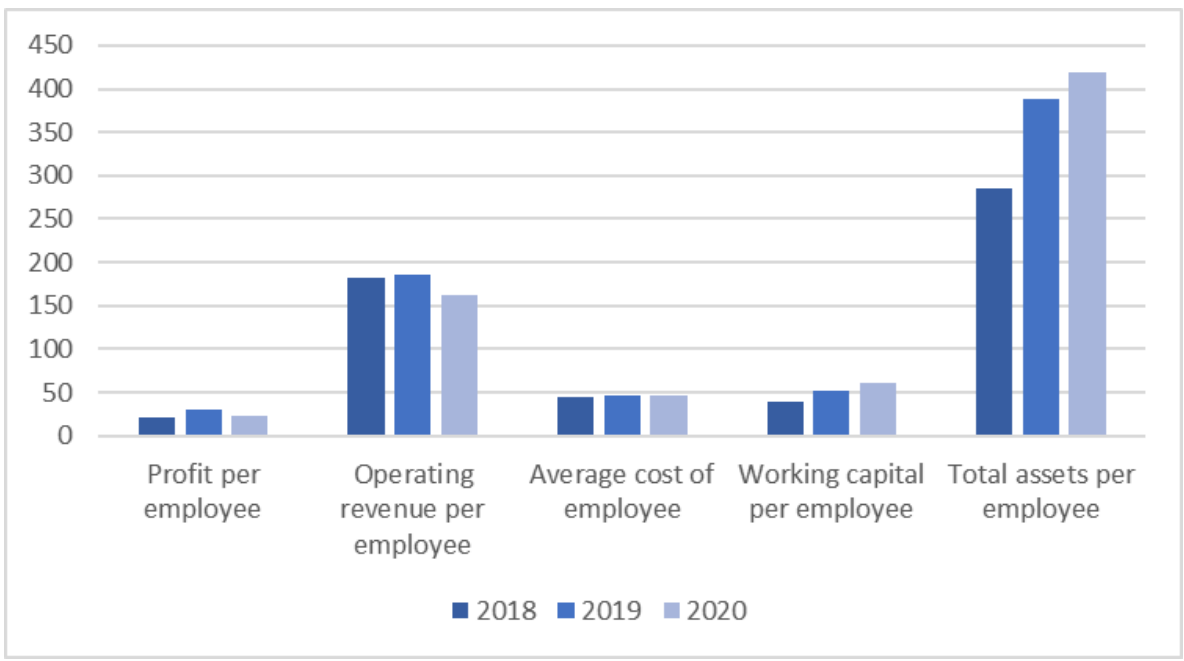

Figure 8. University spinoffs: efficiency ratios

Objective 2): to compare the profitability, structure and efficiency status of university spinoffs and innovative companies.

The following tables show the differences between the means and the results of t-test analysis for profitability status among university spinoffs and innovative companies for the three-years period of analysis. The null hypothesis is tested at $\alpha=5 \%$ level of significance.

Negative values of the differences between the averages are mainly observed in 2018, proving that academic spinoffs record higher values for indicators than innovative companies. The exceptions are Gearing, Operating revenue per employee, Working capital for employee and Total assets for employee. With reference to the first indicator, the positive difference indicates the higher indebtedness of innovative companies compared to unviersity spinoffs. With reference to the positive values found for the remaining three indicators, this indicates a higher efficiency of innovative companies.

For analysis referred to 2018, the null hypothesis is accepted in ROE, EBITDA margin, Cash flow/Operating revenue ratio, Current ratio, Liquidity ratio, Shareholders liquidity ratio, Profit per employee and Working capital per employee since they have a p-value above the level $\alpha=5 \%$. The null hypothesis is rejected in ROA, EBIT margin, Solvency ratio (Asset based), Gearing, Operating revenue per employee, Average cost of employee and Total assets per employee. Thus, for this year of investigation no significant difference between ROE, EBITDA margin, Cash flow/Operating revenue ratio, Current ratio, Liquidity ratio, Shareholders liquidity ratio, Profit per employee and Working capital per employee is observed among innovative companies and academic spinoffs. 
Table 9. T-test results, year 2018

\begin{tabular}{|c|c|c|c|c|c|c|c|}
\hline \multirow[b]{2}{*}{ Profile } & \multirow[b]{2}{*}{ Ratios } & \multirow[b]{2}{*}{$\begin{array}{l}\text { Means for } \\
\text { innovative } \\
\text { companies }\end{array}$} & \multirow[b]{2}{*}{$\begin{array}{r}\text { Means for } \\
\text { academic } \\
\text { spinoffs }\end{array}$} & \multicolumn{3}{|c|}{ Student' } & \multirow[b]{2}{*}{ Decision } \\
\hline & & & & $\begin{array}{r}\text { Differences } \\
\text { between the } \\
\text { means }\end{array}$ & $\begin{array}{r}\text { S } \\
\text { T-test } \\
\text { calculate } \\
\text { d }\end{array}$ & $\begin{array}{r}\text { P- } \\
\text { Value }\end{array}$ & \\
\hline \multirow{6}{*}{$\begin{array}{l}\text { Profitabil } \\
\text { ity }\end{array}$} & ROE (\%) & -4.10 & 2.93 & -7.03 & -0.844 & 0.399 & $\begin{array}{r}\mathrm{H}_{0} \\
\text { accepted }\end{array}$ \\
\hline & ROA (\%) & 0.20 & 5.64 & -5.44 & -3.462 & 0.001 & $\mathrm{H}_{0}$ rejected \\
\hline & Profit margin $(\%)$ & 2.30 & 6.84 & -4.54 & -2.257 & 0.025 & $\mathrm{H}_{0}$ rejected \\
\hline & $\begin{array}{l}\text { EBITDA margin } \\
(\%)\end{array}$ & 9.05 & 10.46 & -1.41 & -0.655 & 0.513 & $\begin{array}{r}\mathrm{H}_{0} \\
\text { accepted }\end{array}$ \\
\hline & EBIT margin $(\%)$ & 3.51 & 7.48 & -3.97 & -1.990 & 0.048 & $\mathrm{H}_{0}$ rejected \\
\hline & $\begin{array}{l}\text { Cash flow / } \\
\text { Operating } \\
\text { revenue }(\%)\end{array}$ & 6.65 & 9.41 & -2.76 & -1.620 & 0.107 & $\begin{array}{r}\mathrm{H}_{0} \\
\text { accepted }\end{array}$ \\
\hline \multirow{3}{*}{ Liquidity } & Current ratio $(\mathrm{x})$ & 2.46 & 2.79 & -0.33 & -1.149 & 0.252 & $\begin{array}{r}\mathrm{H}_{0} \\
\text { accepted }\end{array}$ \\
\hline & $\begin{array}{l}\text { Liquidity ratio } \\
\text { (x) }\end{array}$ & 2.29 & 2.64 & -0.35 & -1.236 & 0.217 & $\begin{array}{r}\mathrm{H}_{0} \\
\text { accepted }\end{array}$ \\
\hline & $\begin{array}{l}\text { Shareholders } \\
\text { liquidity ratio (x) }\end{array}$ & 14.81 & 14.65 & 0.15 & 0.042 & 0.966 & $\begin{array}{r}\mathrm{H}_{0} \\
\text { accepted }\end{array}$ \\
\hline \multirow[t]{2}{*}{ Structure } & $\begin{array}{l}\text { Solvency ratio } \\
\text { (Asset based) } \\
(\%)\end{array}$ & 32.31 & 39.86 & -7.56 & -3.795 & 0.000 & $\mathrm{H}_{0}$ rejected \\
\hline & Gearing (\%) & 126.30 & 94.50 & 31.80 & 2.653 & 0.009 & $\mathrm{H}_{0}$ rejected \\
\hline \multirow{5}{*}{$\begin{array}{c}\text { Efficienc } \\
\mathrm{y}\end{array}$} & $\begin{array}{l}\text { Profit per } \\
\text { employee (th } \\
\text { euro) }\end{array}$ & 19.19 & 20.35 & -1.16 & -0.171 & 0.864 & $\begin{array}{r}\mathrm{H}_{0} \\
\text { accepted }\end{array}$ \\
\hline & $\begin{array}{l}\text { Operating } \\
\text { revenue per } \\
\text { employee (th } \\
\text { euro) }\end{array}$ & 240.16 & 181.36 & 58.80 & 2.301 & 0.022 & $\mathrm{H}_{0}$ rejected \\
\hline & $\begin{array}{l}\text { Average cost of } \\
\text { employee (th } \\
\text { euro) }\end{array}$ & 38.56 & 43.64 & -5.08 & -2.617 & 0.010 & $\mathrm{H}_{0}$ rejected \\
\hline & $\begin{array}{l}\text { Working capital } \\
\text { per employee (th } \\
\text { euro) }\end{array}$ & 45.10 & 38.78 & 6.32 & 0.842 & 0.401 & $\begin{array}{r}\mathrm{H}_{0} \\
\text { accepted }\end{array}$ \\
\hline & $\begin{array}{l}\text { Total assets per } \\
\text { employee (th } \\
\text { euro) }\end{array}$ & 399.89 & 284.91 & 114.98 & 2.525 & 0.012 & $\mathrm{H}_{0}$ rejected \\
\hline
\end{tabular}

Also for 2019, the prevalence of differences between negative averages is confirmed, highlighting that university spinoffs are more profitable and have higher levels of liquidity. For this year of observation, exceptions are represented by Gearing, Operating revenue per employee and Total assets for employee which, recording a positive difference between the means, indicate respectively a greater recourse to indebtedness and better values in the efficiency indicators for innovative companies.

Results of t-test show that the null hypothesis is accepted in Cash flow/Operating revenue ratio, Current ratio, Shareholders liquidity ratio, Profit per employee, Working capital per employee and Total assets per employee. The null hypothesis is rejected in ROE, ROA, Profit margin, EBITDA margin, EBIT margin, Liquidity ratio, Solvency ratio (Asset based), Gearing, Operating revenue per employee and Average cost of employee whose pvalue is less than the level $\alpha=5 \%$. So, for this year no significant difference between Cash flow/Operating revenue ratio, Current ratio, Shareholders liquidity ratio, Profit per employee, Working capital per employee and Total assets per employee is observed comparing innovative companies and academic spinoffs samples. 
Table 10. T-test results, year 2019

\begin{tabular}{|c|c|c|c|c|c|c|c|}
\hline \multirow[b]{2}{*}{ Profile } & \multirow[b]{2}{*}{ Ratios } & \multirow[b]{2}{*}{$\begin{array}{l}\text { Means for } \\
\text { innovative } \\
\text { companies }\end{array}$} & \multirow[b]{2}{*}{$\begin{array}{r}\text { Means for } \\
\text { academic } \\
\text { spinoffs }\end{array}$} & \multicolumn{3}{|c|}{ Student' } & \multirow[b]{2}{*}{ Decision } \\
\hline & & & & $\begin{array}{r}\text { Differences } \\
\text { between the } \\
\text { means }\end{array}$ & $\begin{array}{r}\text { S } \\
\text { T-test } \\
\text { calculate } \\
d\end{array}$ & $\begin{array}{r}\text { P- } \\
\text { Value }\end{array}$ & \\
\hline \multirow{6}{*}{$\begin{array}{l}\text { Profitabil } \\
\text { ity }\end{array}$} & ROE (\%) & -3.93 & 11.98 & -15.92 & -3.346 & 0.001 & $\mathrm{H}_{0}$ rejected \\
\hline & ROA (\%) & -0.22 & 4.62 & -4.83 & -2.921 & 0.004 & $\mathrm{H}_{0}$ rejected \\
\hline & Profit margin (\%) & 1.42 & 7.77 & -6.35 & -3.125 & 0.002 & $\mathrm{H}_{0}$ rejected \\
\hline & $\begin{array}{l}\text { EBITDA margin } \\
(\%)\end{array}$ & 8.56 & 12.89 & -4.33 & -2.329 & 0.021 & $\mathrm{H}_{0}$ rejected \\
\hline & EBIT margin (\%) & 2.37 & 8.49 & -6.12 & -3.077 & 0.002 & $\mathrm{H}_{0}$ rejected \\
\hline & $\begin{array}{l}\text { Cash flow / } \\
\text { Operating } \\
\text { revenue }(\%)\end{array}$ & 6.65 & 9.16 & -2.51 & -1.390 & 0.166 & $\begin{array}{r}\mathrm{H}_{0} \\
\text { accepted }\end{array}$ \\
\hline \multirow{3}{*}{ Liquidity } & Current ratio (x) & 2.24 & 3.33 & -1.09 & -1.962 & 0.051 & $\begin{array}{r}\mathrm{H}_{0} \\
\text { accepted }\end{array}$ \\
\hline & $\begin{array}{l}\text { Liquidity ratio } \\
\text { (x) }\end{array}$ & 2.07 & 3.16 & -1.09 & -1.977 & 0.050 & $\mathrm{H}_{0}$ rejected \\
\hline & $\begin{array}{l}\text { Shareholders } \\
\text { liquidity ratio (x) }\end{array}$ & 16.21 & 13.70 & 2.51 & 0.656 & 0.512 & $\begin{array}{r}\mathrm{H}_{0} \\
\text { accepted }\end{array}$ \\
\hline \multirow[t]{2}{*}{ Structure } & $\begin{array}{l}\text { Solvency ratio } \\
\text { (Asset based) } \\
(\%)\end{array}$ & 33.85 & 39.85 & -6.01 & -3.152 & 0.002 & $\mathrm{H}_{0}$ rejected \\
\hline & Gearing $(\%)$ & 123.06 & 90.41 & 32.65 & 3.222 & 0.001 & $\mathrm{H}_{0}$ rejected \\
\hline \multirow{5}{*}{$\begin{array}{c}\text { Efficienc } \\
\mathrm{y}\end{array}$} & $\begin{array}{l}\text { Profit per } \\
\text { employee (th } \\
\text { euro) }\end{array}$ & 15.51 & 30.72 & -15.21 & -1.767 & 0.079 & $\begin{array}{r}\mathrm{H}_{0} \\
\text { accepted }\end{array}$ \\
\hline & $\begin{array}{l}\text { Operating } \\
\text { revenue per } \\
\text { employee (th } \\
\text { euro) }\end{array}$ & 246.87 & 186.22 & 60.65 & 2.640 & 0.009 & $\mathrm{H}_{0}$ rejected \\
\hline & $\begin{array}{l}\text { Average cost of } \\
\text { employee (th } \\
\text { euro) }\end{array}$ & 40.72 & 45.60 & -4.88 & -3.232 & 0.001 & $\mathrm{H}_{0}$ rejected \\
\hline & $\begin{array}{l}\text { Working capital } \\
\text { per employee (th } \\
\text { euro) }\end{array}$ & 46.83 & 52.51 & -5.68 & -0.376 & 0.707 & $\begin{array}{r}\mathrm{H}_{0} \\
\text { accepted }\end{array}$ \\
\hline & $\begin{array}{l}\text { Total assets per } \\
\text { employee (th } \\
\text { euro) }\end{array}$ & 432.04 & 387.85 & 44.19 & 0.400 & 0.689 & $\begin{array}{r}\mathrm{H}_{0} \\
\text { accepted }\end{array}$ \\
\hline
\end{tabular}

With reference to 2020, positive differences in average values are observed only for the Shareholders liquidity ratio, Gearing, Operating revenue per employee and Total assets per employee indicators. In all other cases, the average values recorded for academic spinoffs are higher than those recorded for innovative companies showing higher levels of profitability, liquidity and efficiency.

The null hypothesis is accepted only for EBITDA margin, Cash flow/Operating revenue ratio, Shareholders liquidity ratio, Profit per employee, Working capital per employee and Total assets per employee proving no significant differences between the two samples. 
Table 11. T-test results, year 2020

\begin{tabular}{|c|c|c|c|c|c|c|c|}
\hline \multirow[b]{2}{*}{ Profile } & \multirow[b]{2}{*}{ Ratios } & \multirow[b]{2}{*}{$\begin{array}{l}\text { Means for } \\
\text { innovative } \\
\text { companies }\end{array}$} & \multirow[b]{2}{*}{$\begin{array}{r}\text { Means for } \\
\text { academic } \\
\text { spinoffs }\end{array}$} & \multicolumn{3}{|c|}{ Student' } & \multirow[b]{2}{*}{ Decision } \\
\hline & & & & $\begin{array}{r}\text { Differences } \\
\text { between the } \\
\text { means }\end{array}$ & $\begin{array}{r}\text { S } \\
\text { T-test } \\
\text { calculate } \\
d\end{array}$ & $\begin{array}{r}P- \\
\text { Value }\end{array}$ & \\
\hline \multirow{6}{*}{$\begin{array}{l}\text { Profitabil } \\
\text { ity }\end{array}$} & ROE (\%) & -4.71 & 5.73 & -10.45 & -2.163 & 0.032 & $\mathrm{H}_{0}$ rejected \\
\hline & ROA (\%) & 0.34 & 3.56 & -3.22 & -2.030 & 0.044 & $\mathrm{H}_{0}$ rejected \\
\hline & Profit margin (\%) & 0.83 & 7.38 & -6.55 & -3.019 & 0.003 & $\mathrm{H}_{0}$ rejected \\
\hline & $\begin{array}{l}\text { EBITDA margin } \\
(\%)\end{array}$ & 7.91 & 12.41 & -4.50 & -1.919 & 0.057 & $\begin{array}{r}\mathrm{H}_{0} \\
\text { accepted }\end{array}$ \\
\hline & EBIT margin (\%) & 1.84 & 7.66 & -5.82 & -2.626 & 0.009 & $\mathrm{H}_{0}$ rejected \\
\hline & $\begin{array}{l}\text { Cash flow / } \\
\text { Operating revenue } \\
(\%)\end{array}$ & 6.03 & 9.13 & -3.10 & -1.441 & 0.151 & $\begin{array}{r}\mathrm{H}_{0} \\
\text { accepted }\end{array}$ \\
\hline \multirow{3}{*}{ Liquidity } & Current ratio (x) & 2.39 & 3.47 & -1.08 & -2.376 & 0.019 & $\mathrm{H}_{0}$ rejected \\
\hline & Liquidity ratio (x) & 2.22 & 3.28 & -1.06 & -2.342 & 0.020 & $\mathrm{H}_{0}$ rejected \\
\hline & $\begin{array}{l}\text { Shareholders } \\
\text { liquidity ratio (x) }\end{array}$ & 17.07 & 17.12 & -0.05 & -0.008 & 0.994 & $\begin{array}{r}\mathrm{H}_{0} \\
\text { accepted } \\
\end{array}$ \\
\hline \multirow[t]{2}{*}{ Structure } & $\begin{array}{l}\text { Solvency ratio } \\
\text { (Asset based) (\%) }\end{array}$ & 36.50 & 44.98 & -8.49 & -4.285 & 0.000 & $\mathrm{H}_{0}$ rejected \\
\hline & Gearing (\%) & 122.94 & 83.33 & 39.60 & 3.994 & 0.000 & $\mathrm{H}_{0}$ rejected \\
\hline \multirow{5}{*}{$\begin{array}{c}\text { Efficienc } \\
y\end{array}$} & $\begin{array}{l}\text { Profit per } \\
\text { employee (th } \\
\text { euro) }\end{array}$ & 18.83 & 22.20 & -3.37 & -0.704 & 0.482 & $\begin{array}{r}\mathrm{H}_{0} \\
\text { accepted }\end{array}$ \\
\hline & $\begin{array}{l}\text { Operating revenue } \\
\text { per employee (th } \\
\text { euro) }\end{array}$ & 278.76 & 161.32 & 117.44 & 5.868 & 0.000 & $\mathrm{H}_{0}$ rejected \\
\hline & $\begin{array}{l}\text { Average cost of } \\
\text { employee (th } \\
\text { euro) }\end{array}$ & 39.77 & 46.39 & -6.62 & -4.330 & 0.000 & $\mathrm{H}_{0}$ rejected \\
\hline & $\begin{array}{l}\text { Working capital } \\
\text { per employee (th } \\
\text { euro) }\end{array}$ & 50.50 & 60.70 & -10.19 & -0.521 & 0.603 & $\begin{array}{r}\mathrm{H}_{0} \\
\text { accepted }\end{array}$ \\
\hline & $\begin{array}{l}\text { Total assets per } \\
\text { employee (th } \\
\text { euro) }\end{array}$ & 572.98 & 418.62 & 154.36 & 1.272 & 0.205 & $\begin{array}{r}\mathrm{H}_{0} \\
\text { accepted }\end{array}$ \\
\hline
\end{tabular}

\section{Conclusions}

This investigation is part of a line of research related to the PRIN project "University spin-offs: competitiveness, attractiveness and value" aimed at analyzing the performance, riskiness and financial policies as well as the creation of value of academic spinoffs compared to innovative companies. In particular, this study aims to ascertain the differential performance of Italian university spinoffs compared to innovative companies. For this reason, the profitability, liquidity, structure and efficiency ratios were analyzed. Findings show that Italian university spinoffs are characterized throughout the period under analysis (2018-2020) by better values of profitability, liquidity, structure and efficiency indicators if compared to start-ups and innovative SMEs. Based on the T-test statistical significance, a prevalence of rejection of the null hypothesis is observed especially for the years 2019 and 2020, highlighting the existence of significant differences in the profitability, liquidity, structure and efficiency profile between two groups of companies.

The study has some limitation. First of all, data are collected exclusively by Amadeus and therefore the study is affected by the availability, accuracy, reliability and quality of the financial statements in the database. Furthermore, the analysis covers a relatively short period of three years (2018-2020). The extension of the time 
horizon could in fact allow the creation of an adequate information base for identifying trends over the period, building historical series consistent with the fairly recent phenomenon of university spin-offs.

\section{References}

Åstebro, T., Bazzazian, N. and Braguinsky, S. (2012) 'Startups by recent university graduates and their faculty: Implications for university entrepreneurship policy’, Research Policy, Vol. 41, No. 4, pp.663-677.

Bramwell, A. and Wolfe, D.A. (2008) 'Universities and regional economic development: the entrepreneurial University of Waterloo', Research Policy, Vol. 37, No. 8, pp.1175-1187.

Breznitz, S.M. (2011) 'Improving or impairing? Following technology transfer changes at the University of Cambridge', Regional Studies, Vol. 45, No. 4, pp.463-478. Breznitz, S.M. and Feldman, M.P. (2012) 'The engaged university', The Journal of Technology Transfer, Vol. 37, No. 2, pp.139-157. Breznitz, S.M., O’Shea, R.P. and Allen, T.J. (2008) 'University commercialization strategies in the development of regional bioclusters', Journal of Product Innovation Management, Vol. 25, No. 2, pp.129-142.

Chukwunweike, V. (2014). The Impact of Liquidity on Profitability of Some Selected Companies: The Financial Statement Analysis (FSA) Approach. Research Journal of Finance and Accounting, 5(5), 81-90.

Clarysse B., Lockett A., Quince T., Van de Velde E. (2002). Spinning off new ventures: a typology of facilitating services, Institute for the Promotion of Innovation by Science and Technology in Flanders, IWT-Observatory, Innovation, Science, Technology, 41.

Clarysse, B., Wright, M., Lockett, A., \& Van de Velde, E. (2011). Entrepreneurial origin, technological knowledge and the growth of spin-off companies. Journal of Management Studies, 48(6), 1420-1442.

Clarysse, B.,Wright, M., Lockett, A.,Van de Velde, E., \& Vohara, A. (2005). Spinning out new ventures: a typology of incubation strategies from European research institutions. Journal of Business Venturing, 20, 183-216.

Conti G., Granieri M., \& Piccaluga A., (2011). La gestione del trasferimento tecnologico. Strategie, Modelli e Strumenti. Springer, Milano.

Crespi, G.A., Geuna, A., \& Nesta, L. (2007). The mobility of university inventors in Europe. The Journal of Technology Transfer, 32(3), 195-215.

Di Gregorio, D., \& Shane, S. (2003). Why do some universities generate more start-ups than others?. Research Policy, 32(2), 209-227.

Djokovic, D., \& Souitaris, V. (2008). Spinouts from Academic Institutions: A Literature Review with Suggestions for Further Research. The Journal of Technology Transfer, 33(3), 225-247.

Egeln, J., Gottschalk, S., Rammer, C. \& Spielkamp, A. (2003). Public Research Spin-offs in Germany, Summary Report, ZEW Documentation 03-04, Centre for European Economic Research, Mannheim.

Fini, R., Fu, K., Mathisen, M., Rasmussen, E., and Wright, M. (2016). Institutional Determinants of University SpinOff Quantity and Quality: A Longitudinal, Multi-Level, Cross-Country Study. Retrieved March 9, 2017, from https://ssrn.com/abstract=2797678

Foster, G. (1986). Financial Statement Analysis, Prentice-Hall, New York, NY.

Friedman, J., \& Silberman, J. (2003). 'University technology transfer: do incentives, management, and location matter?. The Journal of Technology Transfer, 28(1), 17-30.

Lach, S., \& Schankerman, M. (2004). Royalty sharing and technology licensing in universities. Journal of the European Economic Association, 2(2-3), 252-264.

Lach, S., \& Schankerman, M. (2008). Incentives and invention in universities. The RAND Journal of Economics, 39(2), 403-433.

Lev, B. (1974), Financial Statement Analysis: A New Approach, Prentice-Hall, New York, NY.

Goldfarb, B., \& Henrekson, M. (2003). Bottom-up versus top-down policies towards the commercialization of university intellectual property. Research Policy, 32(4), 639-658.

Gompers, P.P.A., \& Lerner, J. (2004). The Venture Capital Cycle. MIT press, Cambridge, MA.

Lockett, A., \& Wright, M. (2005). Resources, capabilities, risk capital and the creation of university spin-out companies. Research Policy, 34(7), 1043-1057.

Moray, N., \& Clarysse, B. (2005). Institutional change and resource endowments to science-based entrepreneurial firms. Research Policy, 34, 1010-1027.

Mun, T. and Tashmanov, G. D. (2021), Financial Statement Analysis Processes According Performance Of Textile Companies In Uzbekistan. International Finance and Accounting, 2021(5), 1-11. 
Nicolaou, N., \& Birley, S. (2003). Academic networks in a trichotomous categorisation of university spinouts. Journal of Business Venturing, 18(3), 333-359.

Powers, J.B., \& McDougall, P.P. (2005). University start-up formation and technology licensing with firms that go public: a resource-based view of academic entrepreneurship. Journal of Business Venturing, 20(3), 291-311.

Ou, J., \& Penman, S. (1989). Financial statement analysis and the prediction of stock returns. Journal of Accounting and Economics, 11, 295-329.

Rinaldo, N. E., \& Endri, E. (2020). Analysis of Financial Performance of Plantation Sub-Sector Companies Listed on the Indonesia Stock Exchange for the 2014-2019 Period. International Journal of Innovative Science and Research Technology, 5(4), 530-537

Roberts, E., \& Malone, D. E. (1996). Policies and structures for spinning off new companies from research and development organizations. $R \& D$ management, 26, 17-48.

Rogers, E. M., Takegami, S., \& Yin, J. (2001). Lessons learned about technology transfer. Technovation, 21(4), 253-261.

Rothaermel, F., Agung, S., and Jiang, L. (2007). University entrepreneurship: a taxonomy of the literature. Industrial and Corporate Change, 16(4), 691-791.

Saxenian, A. (1996) Regional Advantage: Culture and Competition in Silicon Valley and Route 128, Harvard University Press, Cambridge, MA.

Shane S. (2004). Academic entrepreneurship: University spin-offs and wealth creation. Cheltenham, UK: Edward Elgar.

Shane, S., \& Stuart, T. (2002). Organizational endowments and the performance of university start-ups. Management Science, 48(1), 154-170.

Siegel, D., and Wright, M. (2015). Academic entrepreneurship: time for a rethink?. ERC Research Paper, No. 32.

Solanki, K. J., \& Devmurari U. J. (2021). A Study of Financial Statement Analysis of Selected Automobile Companies in India with Special Reference to Goods and Services Tax. Vidhyayana, 7(2), 1-10. 